\title{
Decrease in Circulating and Urine Adrenomedullin Concentrations in Stroke-Prone Spontaneously Hypertensive Rats
}

\author{
Shuji Hirano, Yuichiro Ishiyama, Takeshi Matsuo, Takuroh Imamura, Junichiro Sakata, \\ Kazuo Kitamura, Yasushi Koiwaya, and Tanenao Eto
}

\begin{abstract}
Adrenomedullin (AM) is a peptide with potent vasodilatory and hypotensive properties. Plasma AM levels in rats with experimentally induced hypertension, such as Dahl salt-sensitive rats and two-kidney, one-clip hypertensive rats, are higher than those in normotensive rats. We previously noted, however, that plasma AM levels in spontaneously hypertensive rats (SHR) are similar to those in Wistar-Kyoto rats. To define the role of $\mathbf{A M}$ in rats with severe hypertension, we investigated changes in circulating and tissue AM levels in stroke-prone spontaneously hypertensive rats (SHRSP/Izm). The immunoreactive rat $A M$ levels in plasma, urine, and tissue measured with a sensitive radioimmunoassay, and the AM mRNA levels in various tissues in 15-wk-old SHRSP/Izm were compared with those in age-matched Wistar-Kyoto rats (WKY/Izm). The plasma and urinary AM levels in SHRSP/Izm were significantly lower than those in WKY/Izm [plasma AM, 2.14 \pm 0.06 (SE) vs. 3.24 $\pm 0.16 \mathrm{fmol} / \mathrm{ml}, p<0.001$; urinary AM, 16.36 \pm 3.21 vs. $36.12 \pm 6.09 \mathrm{fmol} / \mathrm{ml}, p<0.01]$. A negative correlation was found between the plasma AM level and the systolic blood pressure in both SHRSP/Izm and WKY/Izm. Reverse-phase high-performance liquid chromatography showed that the molecular components of plasma immunoreactive AM in SHRSP/Izm were similar to those in WKY/Izm. Furthermore, tissue AM levels in various organs in SHRSP/Izm were not lower than those in WKY/Izm. In conclusion, low levels of circulating AM may contribute to the maintenance of high blood pressure in 15-wk-old SHRSP/Izm. These low plasma AM levels may be caused by accelerated metabolism of circulating AM in SHRSP/Izm. (Hypertens Res 1998; 21: 23-28)
\end{abstract}

Key Words: adrenomedullin, gene expression, radioimmunoassay, stroke-prone spontaneously hypertensive rat

Adrenomedullin (AM) is a novel hypotensive peptide discovered in human pheochromocytoma tissue by monitoring activity with respect to increasing cyclic adenosine monophosphate (cAMP) in rat platelets (1). AM consists of 52 amino acids with an intramolecular disulfide bridge. It shares slight homology with calcitonin gene-related peptide (CGRP). Appreciable concentrations of AM are found in normal human plasma and urine $(2,3)$. Furthermore, abundant AM mRNA is expressed in the adrenal medulla, heart, lung, and kidney in both humans and rats $(2,4)$. The intravenous injection of AM elicits potent, long-lasting, vasodilating and hypotensive effects in anesthetized rats (5). Ishimitsu et al. have reported that plasma AM levels are higher in patients with essential hypertension than in normotensive subjects. Moreover, the plasma AM level positively correlates with the severity of hypertension (6). These findings suggest that AM may act as a circulating hormone in the regulation of blood pressure. Shimokubo et al. (7) reported that the plasma AM levels in spontaneously hypertensive rats (SHR) were not higher than those in Wistar-Kyoto rats (WKY). However, there is no report on the circulating and tissue AM levels in stroke-prone spontaneously hypertensive rats (SHRSP/Izm), and the pathophysiological role of AM in severe hypertension is still obscure. As the first step in elucidating the pathophysiological role of $\mathrm{AM}$ in severe hypertension, we measured plasma, urine, and tissue AM levels and AM gene expression in 15-wk-old SHRSP/Izm, and compared the results with those in age-matched Wistar-Kyoto rats $(\mathrm{WKY} / \mathrm{Izm})$.

\section{Methods}

Animals

We used 15-wk-old male SHRSP/Izm $(n=8)$ and age-matched male WKY/Izm $(n=8)$ for measurement of immunoreactive rat AM (ir-rAM) and for RNA blot analysis. All rats were obtained from the

From the First Department of Internal Medicine, Miyazaki Medical College, Miyazaki, Japan.

Address for Reprints: Tanenao Eto, M.D., First Department of Internal Medicine, Miyazaki Medical College, Kihara 5200, Kiyotake, Miyazaki 889-1692, Japan.

Received August 30, 1997; accepted in revised form February 17, 1998. 
Disease Model Cooperative Research Association (Kyoto, Japan). They were housed in a temperature- and light-controlled environment and maintained on standard rat chow (CE-2; CLEA Japan, Tokyo, Japan). The rats had free access to tap water.

\section{Preparation of Urine and Plasma Samples}

Twenty-four-hour urine specimens were collected in tubes containing aprotinin (final concentration, 70 $\mu \mathrm{g} / \mathrm{ml}$ ) and EDTA-2Na (final concentration, 1.5 $\mathrm{mg} / \mathrm{ml}$ ) in metabolic cages. After we measured the systolic blood pressure and the pulse rate by the tail-cuff method, we killed the rats by decapitation. Whole blood was collected in ice-cooled tubes containing aprotinin (final concentration, $70 \mu \mathrm{g} / \mathrm{ml}$ ) and EDTA $2 \mathrm{Na}$ (final concentration, $1.5 \mathrm{mg} / \mathrm{ml}$ ). The urine and the plasma samples, obtained by centrifugation at $3,000 \times g$ for $10 \mathrm{~min}$ at $4^{\circ} \mathrm{C}$, were diluted with an equal volume of saline. These samples were loaded on a Sep-Pak C-18 cartridge $(0.9 \mathrm{ml}$, Waters, MA, USA) preequilibrated with saline. The cartridge was washed with saline, and adsorbed materials were eluted with $4 \mathrm{ml}$ of $60 \%$ acetonitrile containing $0.1 \%$ trifluoroacetic acid (TFA). The eluate was evaporated in a vacuum to dryness and stored before use for measurement of ir-rAM.

\section{Preparation of Tissue Samples for Radioimmunoas-} say

After decapitation, the atria, ventricles, lungs, adrenal glands, kidneys, brain (without pituitary gland), and aorta (from the thoracic aorta to the abdominal aorta) from six rats in each group were resected, quickly frozen with liquid nitrogen, and stored at $-80^{\circ} \mathrm{C}$ until use. These tissues were weighed, diced and boiled in five volumes of $1 \mathrm{M}$ acetic acid for $10 \mathrm{~min}$ to inactivate intrinsic proteases. Boiled tissues were homogenized with a Polytron mixer for $2 \mathrm{~min}$. The supernatant of the extract, obtained by centrifugation at $18,000 \times g$ for $30 \mathrm{~min}$, was diluted with an equal volume of distilled water and applied to the Sep-Pak C-18 cartridge, which was preequilibrated with $0.5 \mathrm{M}$ acetic acid. Adsorbed materials were then eluted with 4 $\mathrm{ml}$ of $60 \%$ acetonitrile containing $0.1 \%$ TFA after washing the cartridge with $0.5 \mathrm{M}$ acetic acid. The eluate was evaporated in a vacuum to dryness and stored until use for measurement of ir-rAM.

\section{Radioimmunoassay for ir- $r A M$}

Radioimmunoassay (RIA) for rat AM was carried out by a previously described method (4) using an antiserum (\#172CI-7) against human AM [40-52] $\mathrm{CONH}_{2}$, which shows $100 \%$ crossreactivity with rat AM. The incubation buffer for the RIA was $50 \mathrm{mM}$ sodium phosphate buffer ( $\mathrm{pH} 7.4)$ containing $0.5 \%$ $N$-ethylmaleimide-treated bovine serum albumin (BSA), $0.5 \%$ Triton $\mathrm{X}-100,80 \mathrm{mM}$ sodium chloride, $25 \mathrm{mM}$ EDTA $2 \mathrm{Na}$, and $0.05 \%$ sodium azide. Each sample with unknown radioactivity or $100 \mu \mathrm{l}$ of standard rat AM was incubated for $12 \mathrm{~h}$ with 50 $\mu l$ of the antiserum diluent, followed by addition of $50 \mu \mathrm{l}$ of the ${ }^{125} \mathrm{I}$-labelled ligand $\left(18,000 \mathrm{cpm},{ }^{125} \mathrm{IN}\right.$
Tyr $\cdot \mathrm{AM}[40-52] \mathrm{CONH}_{2}$ ), iodinated by the peroxidase method. After additional incubation for $24 \mathrm{~h}$, free and bound tracers were separated by centrifugation $(2,000 \times g, \quad 30 \mathrm{~min})$ in the presence of polyethyleneglycol (MW 6,000) and bovine $\gamma$-globulin. The supernatant was aspirated, and the radioactivity in the pellet was counted with a $\gamma$ counter (Aloka ARC-600). The assay was performed in duplicate at $4^{\circ} \mathrm{C}$.

\section{Characterization of ir-rAM in Plasma}

Plasma samples $(21 \mathrm{ml}$ eq.) treated with the SepPak C-18 cartridge were analyzed by reverse-phase high-performance liquid chromatography (HPLC), using a column of TSK ODS $120 \mathrm{~A}(4.6 \times 150 \mathrm{~mm})$ with a linear gradient elution of $\mathrm{CH}_{3} \mathrm{CN}$ from $10 \%$ to $60 \%$ in a solution of $0.1 \%$ TFA. An aliquot of each fraction was submitted to RIA for rat AM.

\section{Total RNA Extraction and Northern Blot Analysis}

After decapitation, the tissues from two rats in each group were resected, quickly frozen with liquid nitrogen, and stored at $-80^{\circ} \mathrm{C}$ until use for RNA extraction. Total RNA from the tissues was extracted by the acid guanidium thiocyanate-phenol-chloroform method $(8)$. Total RNA (30 $\mu \mathrm{g})$ was mixed with $1 \mathrm{M}$ glyoxal, $50 \%$ dimethylsulfoxide (DMSO), and $10 \mathrm{mM} \mathrm{NaH}{ }_{2} \mathrm{PO}_{4}(\mathrm{pH} 7.0)$ and incubated for 1 $\mathrm{h}$ at $50^{\circ} \mathrm{C}$ to cause denaturation. After addition of sterile loading buffer to the samples, denatured RNA was electrophoresed in a $1 \%$ agarose gel containing $0.01 \mathrm{M} \mathrm{NaH}_{2} \mathrm{PO}_{4}(\mathrm{pH} \mathrm{7.0)}$, transferred to a Zeta-probe membrane (Bio-Rad), and fixed by ultraviolet irradiation. The filter was prehybridized for $3 \mathrm{~h}$ at $37^{\circ} \mathrm{C}$ in $0.5 \%$ sodium dodecyl sulphate (SDS), $6 \times \mathrm{SSC}(0.9 \mathrm{M} \mathrm{NaCl}, 90 \mathrm{mM}$ sodium citrate, $\mathrm{pH} 7.0), 50 \%$ formamide, $5 \times$ Denhardt's solution $(0.1 \%$ polyvinylpyrrolidone, $0.1 \%$ Ficol, $0.1 \%$ bovine serum albumin) and $100 \mu \mathrm{g} / \mathrm{ml}$ salmon sperm DNA, and then hybridized overnight under the same conditions plus the addition of a ${ }^{32} \mathrm{P}$-labelled probe at the same temperature. The EcoR $\mathrm{I} / \mathrm{Bgl}$ I cDNA fragment of rat AM corresponding to nucleotides -153 to 422 was radiolabelled with $\left[\alpha^{-32} \mathrm{P}\right]$ dCTP by the random primed labelling method (9) and used as a probe for hybridization. The filter was washed several times with $0.3 \mathrm{M} \mathrm{NaCl}, 30 \mathrm{mM}$ sodium citrate, and $0.1 \% \mathrm{SDS}$ at $55^{\circ} \mathrm{C}$. After stripping the radioactive probe from the membrane by boiling in $0.1 \%$ SDS, it was rehybridized with a ${ }^{32} \mathrm{P}-$ labelled rat glyceraldehyde-3-phosphate dehydrogenase (GAPDH) cDNA probe (EcoR I/BamH I fragment; 492 to 799) for use as an internal standard. The band intensity was estimated with a bioimage analyzer (BAS 2,000, Fuji).

\section{Evaluation of Renal Function and Urinary Excretion of Proteins}

The creatinine concentration in plasma and the concentrations of both total protein and microalbumin in urine were measured as described previously.

Statistical Analysis

All data are expressed as means \pm SEM. The statis- 
Table 1. Profiles of SHRSP/Izm and WKY/Izm.

\begin{tabular}{lcc}
\hline & SHRSP/Izm $(n=8)$ & WKY/Izm $(n=8)$ \\
\hline Body weight $(\mathrm{g})$ & $301 \pm 4^{*}$ & $341 \pm 7$ \\
Pulse rate $($ beats/min) & $350 \pm 10$ & $364 \pm 5$ \\
Systolic blood pressure $(\mathrm{mmHg})$ & $200 \pm 5^{*}$ & $117 \pm 3$ \\
Serum creatinine $(\mathrm{mg} / \mathrm{dl})$ & $0.30 \pm 0.02$ & $0.34 \pm 0.02$ \\
Urinary total protein $(\mathrm{mg} / \mathrm{d})$ & $22.7 \pm 2.3$ & $19.0 \pm 1.9$ \\
Urinary albumin $(\mu \mathrm{g} / \mathrm{d})$ & $685 \pm 119^{*}$ & $95.6 \pm 8.3$ \\
\hline
\end{tabular}

Values are means \pm SEM, $* p<0.001 v s$. age-matched WKY/Izm.

Table 2. Tissue ir-rAM Concentrations in SHRSP/Izm and WKY/Izm.

\begin{tabular}{lcc}
\hline (fmol/mg wet tissue) & SHRSP/Izm & WKY/Izm \\
\hline Brain & $0.087 \pm 0.001^{* *}$ & $0.068 \pm 0.001$ \\
Atrium & $6.27 \pm 0.42$ & $6.72 \pm 0.71$ \\
Ventricle & $0.14 \pm 0.008$ & $0.13 \pm 0.004$ \\
Lung & $7.43 \pm 0.46$ & $7.98 \pm 0.35$ \\
Kidney & $0.19 \pm 0.01 *$ & $0.15 \pm 0.003$ \\
Adrenal gland & $22.4 \pm 2.5$ & $16.6 \pm 1.7$ \\
Aorta & $0.09 \pm 0.02$ & $0.10 \pm 0.01$ \\
\hline
\end{tabular}

Values are means $\pm \operatorname{SEM}(n=6),{ }^{*} p<0.01,{ }^{* *} p<0.001 v s$. age-matched WKY/Izm.
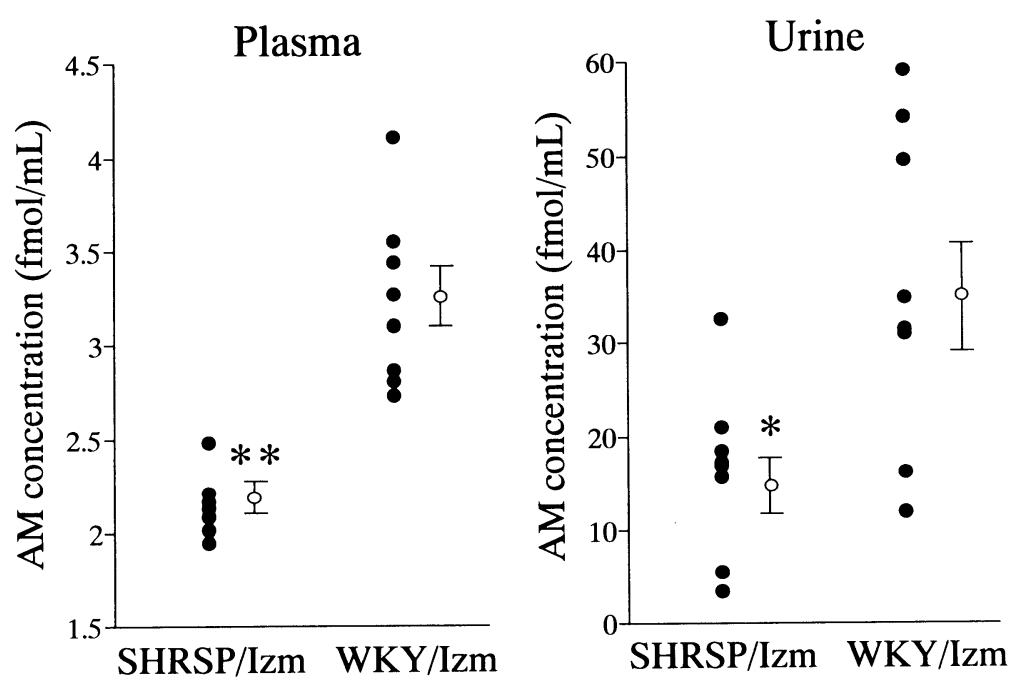

Fig. 1. Plasma (left panel) and urinary (right panel) adrenomedullin (AM) levels in SHRSP/Izm and WKY/Izm. Data for individual rats are presented as closed circles, and open circles and vertical bars indicate the means $\pm S E M$ in each group. $*, \mathrm{p}<0.01 ; * *, \mathrm{p}<0.001$ vs. WKY/Izm.

tical significance of differences between the two groups was evaluated with Student's $t$-test, and linear regression analysis was used to assess the correlation between variables. A $p$ value of $<0.05$ was considered to indicate statistical significance.

\section{Results}

Table 1 summarizes the body weight, pulse rate, systolic blood pressure, serum creatinine concentration, and total 24-h excretion of urinary total protein and albumin in both strains. As compared with
WKY/Izm, SHRSP/Izm had significantly $(p<0.001)$ lower body weight, significantly higher systolic blood pressure $(p<0.001)$, and significantly higher urinary albumin excretion $(p<0.001)$, with no elevation of serum creatinine level.

The ir-rAM levels in plasma and in urine are shown in Fig. 1. The ir-rAM levels in SHRSP/Izm $(n=8)$ were significantly lower than those in WKY/Izm $(n=8)$, both in plasma $(2.14 \pm 0.06 \mathrm{vs}$. $3.24 \pm 0.16 \mathrm{fmol} / \mathrm{ml}, p<0.001)$ and in urine $(16.36$ \pm 3.21 vs. $36.12 \pm 6.09 \mathrm{fmol} / \mathrm{ml}, p<0.01)$. In addition, the total 24-h urinary excretion of AM was 
Table 3. Coefficients for Correlations of the Plasma AM Level with the AM Levels in Urine and Tissue.

\begin{tabular}{lcc}
\hline AM level & Correlation Coefficient $(r)$ & $p$ value \\
\hline Urine & 0.289 & $\mathrm{NS}$ \\
Brain & -0.516 & $\mathrm{NS}$ \\
Atrium & -0.343 & $\mathrm{NS}$ \\
Ventricle & 0.006 & $\mathrm{NS}$ \\
Lung & 0.249 & $\mathrm{NS}$ \\
Kidney & -0.315 & $\mathrm{NS}$ \\
Adrenal gland & -0.106 & $\mathrm{NS}$ \\
Aorta & -0.142 & $\mathrm{NS}$ \\
\hline
\end{tabular}

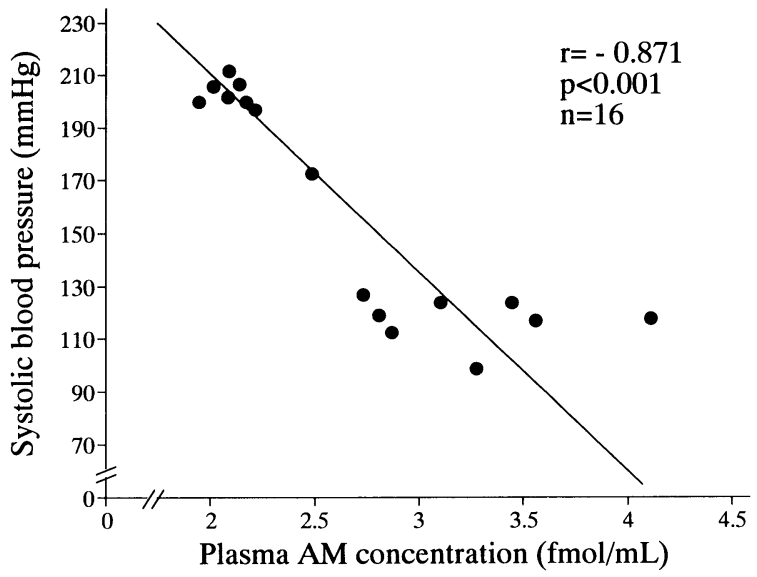

Fig. 2. Relationship between the plasma adrenomedullin (AM) concentration and systolic blood pressure in SHRSP/ Izm and WKY/Izm.

also lower in SHRSP/Izm than in WKY/Izm (243.1 \pm 38.6 vs. $386.1 \pm 46.8 \mathrm{fmol} / \mathrm{d}$ in eight rats in each group, $p<0.05$ ). The plasma AM level negatively correlated with the systolic blood pressure in both SHRSP/Izm and WKY/Izm $(\mathrm{r}=-0.871, p<0.001$, $n=16$ ) (Fig. 2). There was no difference in urine volume between the two strains.

The tissue ir-rAM levels in SHRSP/Izm and WKY/Izm are summarized in Table 2. The tissue AM level in each organ in SHRSP/Izm was not lower than that in WKY/Izm. The levels in the brain, kidney, and adrenal gland were slightly higher in SHRSP/Izm than in WKY/Izm. There was no difference in the levels in the atria, lung, or aorta between the two strains.

The coefficients for the correlations of the plasma AM level with the AM level in the urine and each tissue are shown in Table 3. No significant correlation was found.

Figure 3 shows typical results of RNA blot analysis in SHRSP/Izm (SP) and WKY/Izm (W). The upper panel shows the bands hybridizing to the rat AM cDNA probe, found at about $1.6 \mathrm{~kb}$. Very intense bands hybridizing to rat AM cDNA were observed in the adrenal gland, cardiac atria, ventricle, and lung in both strains. The membrane used for analysis of AM mRNA was re-hybridized to GAPDH cDNA probe to serve as an internal standard. The lower panel shows the results for GAPDH mRNA. In the analysis, the band intensity of rat AM was corrected based on that of GAPDH. Several hybridization experiments disclosed that the AM mRNA levels in the kidney and the adrenal gland in SHRSP/Izm were higher, by $52 \%$ and $25 \%$ on average, respectively, than those in WKY/Izm. On the other hand, the AM mRNA levels in the cardiac ventricle and the lung of SHRSP/Izm were lower, by $29 \%$ and $15 \%$ on average, respectively, than those in WKY/Izm. The AM mRNA levels in the aorta, atria, and brain were similar in SHRSP/Izm and WKY/Izm; the ratios of the mean values in SHRSP/Izm to those in WKY/Izm were $1.10,0.91$ and 0.90 , respectively.

The molecular forms of plasma AM in SHRSP/ Izm and WKY/Izm were characterized by reversephase HPLC. As shown in Fig. 4,. the molecular forms of ir-rAM in plasma were composed of one major peak and several minor peaks in both strains. The major peak of plasma ir-rAM in SHRSP/Izm and WKY/Izm emerged at the position identical to that of authentic rat AM [1-50]. Several minor peaks of plasma ir-rAM also emerged in both strains, and the elution patterns of these minor peaks were similar in the two strains.

\section{Discussion}

To define the pathophysiological role of AM in SHRSP/Izm, a strain with severe hypertension, we measured the plasma, urine, and tissue levels of AM and its gene expression in 15-wk-old SHRSP/ Izm and age-matched WKY/Izm. Plasma and urinary AM levels were significantly lower in SHRSP/ Izm than in WKY/Izm. Furthermore, there was a negative correlation between the plasma AM level and the systolic blood pressure in both strains.

Our results are inconsistent with those of previous studies of other hypertensive rat models, such as renovascular hypertensive rats (10), Dahl-salt sensitive rats (11), and pulmonary hypertensive rats (12). The assay system that we used to measure rat 


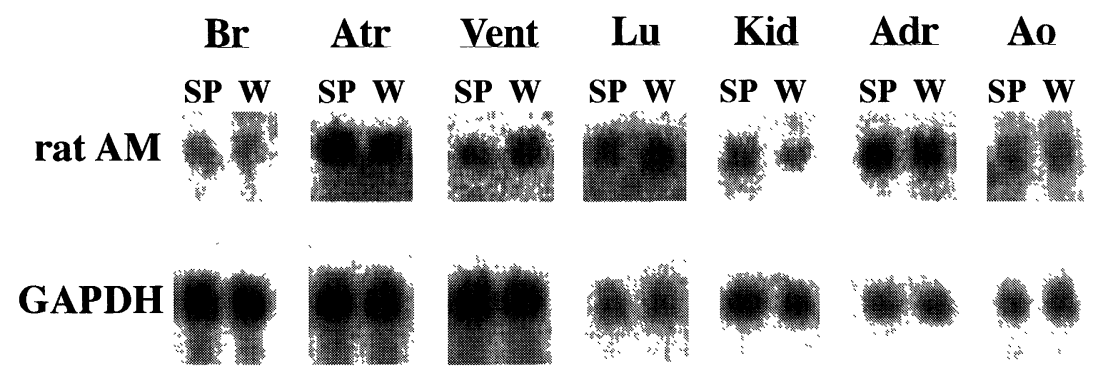

Fig. 3. RNA blot analysis of rat adrenomedullin transcript in each tissue from SHRSP/Izm (SP) and WKY/Izm (W). The upper and lower panels show blots for rat AM and GAPDH $m R N A$, respectively. Each lane contains $30 \mu g$ of total RNA. Br, brain; Atr, atria; Vent, ventricle; Lu, lung; Kid, kidney; Adr, adrenal gland; Ao, aorta.

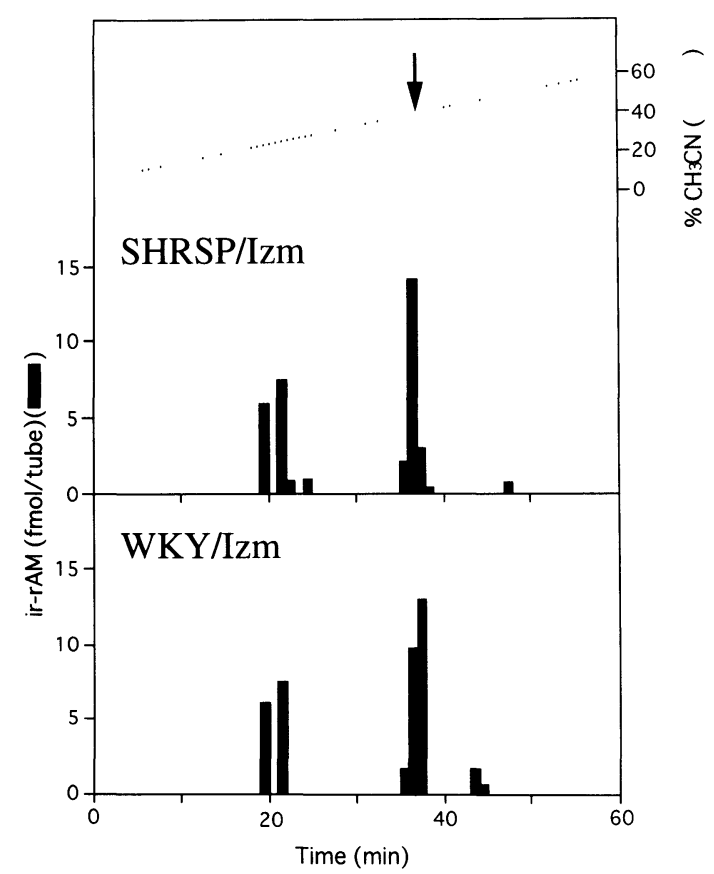

Fig. 4. Reverse-phase HPLC of plasma samples from SHRSP/Izm and WKY/Izm monitored by RIA for rat AM. Samples: $21 \mathrm{ml}$ of rat plasma from each strain were treated with a Sep-Pak $C-18$ cartridge as described in the text. Column: TSK ODS $120 \mathrm{~A}(4.6 \times 120 \mathrm{~mm})$. Flow rate, $1.0 \mathrm{ml} / \mathrm{min}$. Solvent system, a linear gradient elution of $\mathrm{CH}_{3} \mathrm{CN}$ from $10 \%$ to $60 \%$ in $0.1 \%$ TFA over $60 \mathrm{~min}$. The arrow indicates the elution position of authentic rat $A M$. Authentic rat AM was obtained from Peptide Institute, Inc. (Osaka, Japan).

AM was the same as that used in earlier studies, and the plasma AM levels in WKY/Izm were similar to those reported in other normotensive rats (4). Moreover, reverse-phase HPLC analysis showed that the molecular forms of plasma AM in SHRSP/ Izm were similar to those in WKY/Izm. Our results therefore suggest that the production or metabolic processing, or both, of AM in SHRSP/Izm differ considerably from those in other hypertensive rats.

Several articles indicate that bolus or chronic administration of exogenous AM has potent vasodilatory and hypotensive effects on various vascular systems in rats $(5,13)$. However, it remains unknown whether a decrease in the fentomolar concentration of AM can biologically influence the blood pressure. In this study, we found that the mean plasma AM level in SHRSP/Izm was $1.1 \mathrm{fmol} /$ $\mathrm{ml}$ lower than the level in $\mathrm{WKY} / \mathrm{Izm}$. In a recent study, chronic administration of AM in SHR via an osmotic minipump for $2 \mathrm{wk}$ induced only a 0.6 $\mathrm{fmol} / \mathrm{ml}$ increase in the plasma AM level, but there was a significant reduction in blood pressure (14). Thus, the small but significant decrease in circulating AM levels in our study may have contributed to elevation of blood pressure in 15-wk-old SHRSP/ Izm.

Although we could not determine the reason for the lower circulating AM level in SHRSP/Izm, we did obtain several important findings concerning the production and clearance of circulating AM. As for production of AM in tissue, we found no difference in the tissue AM level between the strains. In addition, there was no correlation between the tissue AM levels and the plasma AM level. We found that the AM mRNA expression was higher in the kidney but lower in the ventricle in SHRSP/Izm than in WKY/Izm. However, there is no evidence that low AM mRNA expression in the ventricle directly affects the plasma AM level.

As for clearance of circulating AM, we found that the levels of urinary AM in SHRSP/Izm were lower than those in WKY/Izm, and that the 24-h urinary excretion of AM in SHRSP/Izm was less than that in WKY/Izm. Moreover, there was no relationship between the urinary and the plasma AM levels. These results suggest that decreased production of $\mathrm{AM}$ and increased urinary excretion of AM might not account for the lower plasma AM levels in SHRSP/Izm. Therefore, the lower plasma AM levels in SHRSP/Izm may be caused by accelerated metabolism of circulating AM. Nishimura et al. reported that the relaxant response of the basilar arteries to AM was significantly greater in SHRSP than in WKY rats (15), suggesting that the AM receptors are upregulated in SHRSP. Mechanisms involved in the metabolic processing of circulating AM are unclear at present; additional studies of the clearance of circulating AM and binding to AM re- 
ceptors are necessary to determine the reason for the lower plasma AM levels in the SHRSP/Izm.

Reverse-phase HPLC analysis indicated that the major form of plasma AM was identical to authetic rat AM. However, several minor but reproducible peaks, eluted earlier, were detected on reversephase HPLC. These minor peaks are thought to be peptide fragments of AM, including the carboxy terminal region, which is recognized by antiserum $\# 172 \mathrm{CI}-7$. Further characterization of these minor peaks is now in progress.

In contrast to previous reports, the ventricular AM gene expression in the SHRSP/Izm was low despite marked left ventricular hypertrophy. Several studies report that ventricular hypertrophy is closely related to the elevated ventricular AM gene expression in SHR (7), Dahl-salt sensitive rats (11), and pulmonary hypertensive rats (12). Thus far, the reasons for these conflicting results remain unclear.

In conclusion, both the plasma and urinary AM levels in 15-wk-old SHRSP/Izm are significantly lower than those in age-matched WKY/Izm. These low plasma AM levels in SHRSP/Izm may be caused by accelerated metabolism of circulating $\mathrm{AM}$, rather than by decreased production or increased renal clearance of AM. Furthermore, these lower plasma AM levels may contribute to the elevation of blood pressure in 15-wk-old SHRSP/ Izm.

\section{Acknowledgements}

We thank Miss Mari Kawamoto for her skillful technical assistance.

\section{References}

1. Kitamura K, Kangawa K, Kawamoto M, et al: Adrenomedullin: a novel hypotensive peptide isolated from human pheochromocytoma. Biochem Biophys Res Commun 1993; 192: 553-560.

2. Ichiki Y, Kitamura K, Kangawa K, Kawamoto M, Matsuo H, Eto T: Distribution and characterization of immunoreactive adrenomedullin in human tissue and plasma. FEBS Lett 1994; 338: 6-10.

3. Kitamura $\mathrm{K}$, Ichiki Y, Tanaka M, et al: Immunoreactive adrenomedullin in human plasma. FEBS Lett 1994; 341: 288-290.
4. Sakata J, Shimokubo T, Kitamura K, et al: Distribution and characterization of immunoreactive rat adrenomedullin in tissue and plasma. FEBS Lett 1994; 352: $105-108$.

5. Ishiyama Y, Kitamura K, Ichiki Y, et al: Hemodynamic effects of a novel hypotensive peptide, human adrenomedullin in rats. Eur J Pharmacol 1993; 241: 271-273.

6. Ishimitsu $\mathrm{T}$, Nishikimi $\mathrm{T}$, Saito $\mathrm{Y}$, et al: Plasma levels of adrenomedullin, a newly identified hypotensive peptide in patients with hypertension and renal failure. J Clin Invest 1994; 94: 2158-2161.

7. Shimokubo T, Sakata J, Kitamura K, Kangawa K, Matsuo H, Eto T: Alteration in tissue concentration and gene expression of adrenomedullin in spontaneously hypertensive rats. Pathophysiology 1995; 2: 223-226.

8. Chomczynski P, Sacchi J: Single-step method of RNA isolation by acid guanidinium thiocyanatephenol-chloroform extraction. Anal Biochem 1987; 162: 156-159.

9. Feinberg AP, Vogelstein B: A technique for radiolabeling DNA restriction endonuclease fragments to high specific activity. Anal Biochem 1983; 132: $6-13$

10. Ishiyama Y, Kitamura K, Kato J, Sakata J, Kangawa $\mathrm{K}$, Eto $\mathrm{T}$ : Changes in cardiac adrenomedullin concentration in renovascular hypertensive rats. Hypertens Res 1997; 20: 113-117.

11. Shimokubo T, Sakata J, Kitamura K, Kangawa K, Matsuo H, Eto T: Adrenomedullin: changes in circulating and cardiac tissue concentration in Dahl saltsensitive rats on a high-salt diet. Clin Exp Hypertens 1996; 18: 949-261.

12. Shimokubo T, Sakata J, Kitamura K, Kangawa K, Matsuo H, Eto T: Augmented adrenomedullin concentrations in right ventricle and plasma of experimental pulmonary hypertension. Life Sci 1995; 57: 1771-1779.

13. Nuki C, Kawasaki H, Kitamura K, et al: Vasodilator effect of adrenomedullin and calcitonin gene-related peptide receptors in rat mesenteric vascular beds. Biochem Biophys Res Commun 1993; 196: 245-251.

14. Khan AI, Kato J, Kitamura K, Kangawa K, Eto T: Hypotensive effects of chronically infused adrenomedullin in conscious Wistar-Kyoto and spontaneously hypertensive rats. Clin Exp Pharmacol Physiol 1997; 24: 139-142.

15. Nishimura Y, Suzuki A: Relaxant effects of vasodilator peptides on isolated basilar arteries from strokeprone spontaneously hypertensive rats. Clin Exp Pharmacol Physiol 1997; 24: 157-161. 